\section{Making high-tech champagne}

Biotechnology is about to be applied to those distinctively French wines and cheeses. That is the novel component of the recently approved biotechnology programme of the ministry of research and technology.

The French government and the agrofood manufacturers, France's second largest industrial community, are worried that their traditional methods are too unreliable, variable and sensitive to uncontrollable factors such as the weather to secure their place in the world markets against high-technology producers in California, South Africa and Australia. So the French food producers have decided they will use science to help.

Champagne will be one beneficiary. One of the most difficult elements of champagne technology, rémuage, is the removal of spent yeast from the wine after the second fermentation that produces the "fizz" and the flavour. This is already being changed by the use of "fixed", pelleted yeast. Moët-Hennessy, the producer of Moët et Chandon and many other well-known champagnes, is carefully introducing the new methods.

The company says there is no detectable effect on the flavour, and that the advantage will be that rémuage will take only three days, compared with the present laborious three months of slowly turning and raising the bottles until they are corkdown, followed by a swift opening and closing of the bottle by an expert to blow out the unwanted yeast. With fixed yeast, the same blowing-out is necessary, but the yeast pellets sink far more rapidly than individual yeast cells.

The saving of storage time will increase by 80 per cent the capacity of the champagne cellars that burrow throughout the champagne district, says Moët-Hennessy, which would help iron out the immense fluctuations in champagne production caused by the weather. (Champagne, one of the world's most northerly winegrowing areas, produced 300 million bottles in 1983, but only 80 million in 1981.)

The vines themselves are also under study. The small Programme Nationale de la Vigne, established three years ago by the research ministry, held its first scientific conference last spring and raised hopes that gene cloning and transfer techniques together with cell fusion and tissue culture might well produce useful new varieties. In the past, it has taken between 20 years and a century to make a new clone adapted to a particular soil and climate; this time must be shortened if new varieties resistant to disease or less sensitive to spring frosts, for example, are to be developed.

Cheese production, usually by small local makers, is also in question in a dairy industry which was shocked to hear re- cently that Japan, which is on a wave of fashion for French cuisine, has begun to manufacture its own high-tech but tasty Camembert. This apparently uses French organisms but Australian milk, and thus represents a large market which the small French producers have almost totally lost. Scientifically, the questions again are how to achieve constancy, quality and volume.

At the ministry, the view is that after three years of government aid, biotechnology is already well established in the large French drugs, vaccines, bioreactants, fine chemicals and medical manufacturers, but that the small agrobusinesses now need a helping hand. Many of the companies are too small to have any research effort at all. Hence, according to Pierre Douzou, director of the new gov-

\section{European professions}

Brussels

THE European Commission has drafted legislation laying down the principle of mutual recognition of all higher education diplomas throughout the Community. The aim is to facilitate the mobility of those exercising a profession. The European Commission seems to think this can be achieved without harmonization of national higher education systems. But the draft directive is very much at the beginning of a consultative process in which the European Parliament, industry, employers and various lobby groups, as well as governments, will want their say.

The measure aims at tying up a rather large loose end in Community law, whereby it is illegal to discriminate on the grounds of nationality, so that Community citizens have the right to set up their professional domicile in any of the ten countries of the European Economic Community (EEC), but where paradoxically only nationally acquired qualifications are recognized in order to be able to exercise one's profession. The only exceptions are doctors, veterinarians, dentists and architects, for whom mutual recognition of diplomas already exists.

But whereas in these cases academic curricula were to some extent harmonized throughout the Community as well, this time the Edonnino committee, mandated by heads of state at Fontainebleau in June 1984, recommended, instead, just an overall system of mutual recognition and trust, rather than the time-consuming harmonization of training courses.

The draft directive covers all professions requiring three years of higher (university-type) education which have followed a higher secondary course baccalaureat, abitur or A-level.

It thus applies equally to paramedics

ernment programme mobilisateur for biotechnology, seven out of ten of the industrial advisers for the programme will be drawn from the agrofood industries, and the emphasis of the new programme, supported by FF 115 million ( $£ 11$ million) of seed money for 1986 , will be in agriculture and food.

The new trend has also been emphasized by Douzou's further appointment as chairman of the scientific council of INRA, the national agricultural research organization, which has "many fine scientists" but has been historically somewhat isolated from other French scientific communities, particularly those supported by the national and medical research councils, CNRS and INSERM, and even from the universities.

Douzou sees his job as helping INRA director Jacques Poly to "opening up" INRA to the rest of science.

Robert Walgate

\title{
Plan to make diplomas travel
}

(physiotherapists, opticians, psychologists), the scientific community (engineers, geologists, agronomists), lawyers, journalists, economists, statisticians and teachers.

Information on professional recognition would be available from a computerized network linking up centres that already exist.

While the proposal is clearly an expression of political will on the part of governments towards the European ideal of complete mobility of citizens, making it easier for those whose home market is saturated to move to another EEC country, in practice it may come up against the protectionism and corporatism that characterized some of those professions.

Secondly, it is clear, as the proposal points out, that despite some measure of similarity or comparability, differences between the education and training systems in a given profession will still require the newcomer to obtain further experience or training in the proposed country of establishment. The proposal allows for a maximum period of three years but makes no budgetary provision at Community level, nor does it specify who will pay. Under Community law, a directive lays down the aims but leaves the means of achieving them to the member states. This could give rise to different financial constraints in different member states.

Achieving some level of uniformity between national education systems could further enhance the mobility aimed at by the draft legislation, but there is no provision for harmonizing education in the Rome treaties. Even if EEC education ministers do meet to discuss equal opportunities for students, this is an area in which they jealously guard their sovereignty. Anna Lubinska 